\title{
Analysis of the mechanical properties of polymer composites for the production of machine parts used as substitutes for elements obtained from metals (Rapid communication)
}

\author{
Olimpia Markowska ${ }^{1), *)}$, Tadeusz Markowski ${ }^{1)}$, Magdalena Sobczyk ${ }^{2)}$ \\ DOI: dx.doi.org/10.14314/polimery.2020.4.8
}

\begin{abstract}
The mechanical properties of composites based on polyamide 6 (PA6), polyamide 66 (PA66) and polyphthalamide (PPA) reinforced with fiberglass were tested. Flexural strength, Shore and Rockwell hardness and also notched and without a notch impact strength according to Charpy were determined. The best results of the strength tests were observed for the PA66 composite with $35 \mathrm{wt} \%$ fiberglass. The analyzed composite materials can be successfully used in the production of substitutes for machine elements made of metal.
\end{abstract}

Keywords: polymer composites, mechanical properties, metals, polyamide (PA6), polyamide (PA66), polyphthalamide (PPA), fiberglass.

\section{Analiza właściwości mechanicznych kompozytów polimerowych przeznaczonych do produkcji części maszyn stosowanych jako zamienniki elementów otrzymywanych z metali}

\begin{abstract}
Streszczenie: Zbadano właściwości mechaniczne kompozytów na bazie poliamidu 6 (PA6), poliamidu 66 (PA66) oraz poliftalamidu (PPA) wzmocnionych włóknem szklanym. Oznaczono wytrzymałość na zginanie, udarność wg Charpy'ego z karbem i bez karbu, twardość Shore'a oraz Rockwella. Najlepsze właściwości wytrzymałościowe wykazywał kompozyt PA66 z udziałem 35\% mas. włókna. Oceniane materiały kompozytowe z powodzeniem mogą być stosowane do produkcji zamienników elementów maszyn wykonanych z metali.
\end{abstract}

Słowa kluczowe: kompozyty polimerowe, właściwości mechaniczne, metale, poliamid 6, poliamid 66, poliftalamid, włókno szklane.

Due to the continuous progress of the mechanical and functional properties of polymer materials, the scope of their use in machine construction has been extended [1]. The selection and use of specific fillers and nanofillers, as well as other modifiers, in the production of polymeric materials make it possible to change their properties taking into account the forecasted operating conditions. It should be emphasized that the basic properties of the polymeric materials are clearly different from the previously used metallic materials. Metal alloys are characterized by higher densities, higher melting temperatures and working temperatures, better rigidity and strength properties, as well as better electrical and thermal conductiv- ities. On the other hand, polymer materials better suppress mechanical vibrations [2-4]. The use of polymeric materials as substitutes for metal alloys to ensure the economic efficiency of production usually requires a complete change in the concept of product design (Fig. 1) [5, 6].

At the same time, the use of polymers makes it possible to simplify the design of the product and improve its functionality. It should be emphasized, however, that in similar operating conditions, polymeric materials behave differently compared to metals [7-9].

The purpose of the work described in this article is to analyze the mechanical properties of polymer composites used as replacements for machine components made of metals.

1) Rzeszow University of Technology, The Faculty of Mechanical Engineering and Aeronautics, al. Powstańców Warszawy 12, 35-959 Rzeszów, Poland.

2) Splast Sp. z o.o. Krosno, Lotników 13, 38-400 Krosno, Poland.

*) Authors for correspondence: olimpia@prz.edu.pl 


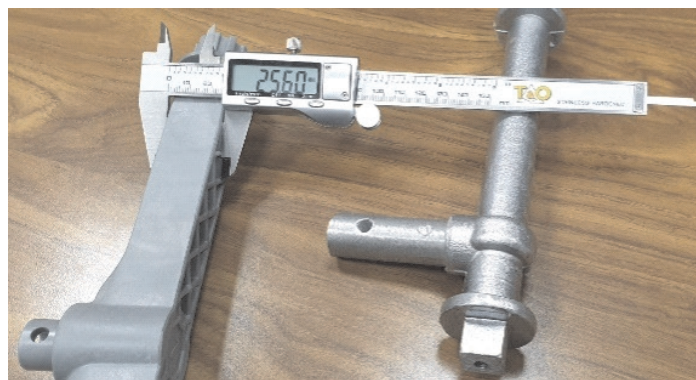

b)

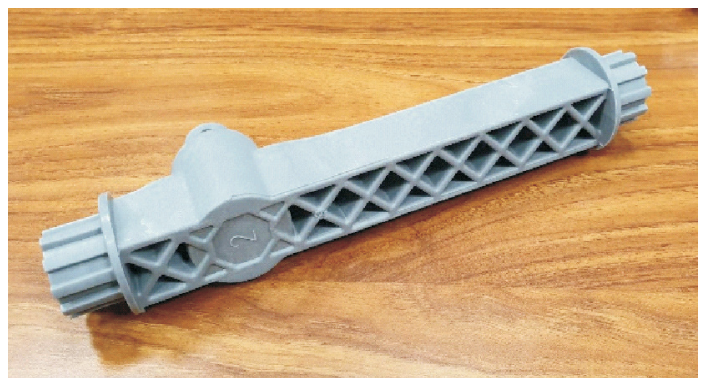

Fig. 1. Machine elements of extrusion press (manufactured at Splast): a) metal shaft, b) composite shaft

$\mathrm{T}$ a b l e 1. Parameters for the plastic drying and injection molding process

\begin{tabular}{l|c|c|c|c|c|c|c}
\hline \multicolumn{1}{c}{ Parameters } & \multicolumn{9}{c}{ Symbol of sample } \\
\cline { 2 - 8 } & $\mathrm{K} 1$ & $\mathrm{~K} 2$ & $\mathrm{~K} 3$ & $\mathrm{~K} 4$ & $\mathrm{~K} 5$ & $\mathrm{~K} 6$ & $\mathrm{~K} 7$ \\
\hline Drying time, h & $2-4$ & $2-4$ & $2-4$ & $2-4$ & $2-6$ & $6-8$ & $6-8$ \\
Drying temperature, ${ }^{\circ} \mathrm{C}$ & 80 & 80 & 80 & 80 & 80 & 100 & 100 \\
Acceptable moisture level, \% & 0.1 & 0.2 & 0.2 & 0.2 & 0.12 & 0.1 & 0.1 \\
Injection temperature min-max, ${ }^{\circ} \mathrm{C}$ & $230-270$ & $280-300$ & $280-290$ & $285-305$ & $280-300$ & $320-330$ & $305-330$ \\
Mold temperature min-max, ${ }^{\circ} \mathrm{C}$ & $60-80$ & $50-90$ & $70-120$ & $70-120$ & $80-120$ & $140-180$ & $140-160$ \\
\hline
\end{tabular}

\section{EXPERIMENTAL PART}

\section{Materials}

Tarnamid T-27 NATUR (PA6), Azoty Tarnów, marked as $\mathrm{K} 1$.

Zytel 101L NC010 (PA66), DuPont, marked as K2.

Zytel PLS95G35DH1 BK549 [PA66 + 35 wt \% of fiberglass (FG)], DuPont, marked as K3.

Zytel PLS95G50DH2 BK261 (PA66 + 45 wt \% of FG), DuPont, marked as K4.

Durethan AKV50H2.0 901510 (PA66 + 50 wt \% of FG), LANXESS Energizing Chemistry, marked as K5.

Zytel HTN51G35HSL NC010 (PPA6 + 35 wt \% of FG),

DuPont, marked as K6.

Grivory HTV-3H1 BLACK 9205 (PPA6 + 30 wt \% of FG), ES CHEMIE AG, marked as K7.

\section{Receiving molds for research}

The molds were obtained using the injection technique via an ENGEL injection molding machine. Before injection, the materials were dried to eliminate moisture, which could result in the formation of defects in the molds during the process, resulting in errors. The exact parameters of the injection process are confidential. Table 1 presents the drying process parameters, as well as injection molding and mold temperatures.

\section{Methods of testing}

\section{Strength test for static bending}

Bending strength tests were carried out in accordance with PN-EN ISO 178 using the INSTRO 535 testing ma-
T a b l e 2. Marked parameters

\begin{tabular}{l|c}
\hline \multicolumn{1}{c|}{ Parameters } & Mark \\
\hline Section indicator, $\mathrm{mm}^{2}$ & $\mathrm{~W}$ \\
Stress at conventional deformation, $\mathrm{MPa}$ & ofC \\
Bending stress, $\mathrm{MPa}$ & $\sigma \mathrm{fB}$ \\
Bending strength, $\mathrm{MPa}$ & $\sigma \mathrm{fM}$ \\
Bending deformation at fracture, $\%$ & $\mathrm{efB}$ \\
Modulus of resilience, $\mathrm{MPa}$ & $E(\mathrm{~b})$ \\
Destructive deflection, $\mathrm{mm}$ & $s \mathrm{~B}$ \\
\hline
\end{tabular}

chine. Three-point bending of rectangular samples with a cross section of $10 \times 4 \mathrm{~mm}$ was performed. The diameter of the supports was $30 \mathrm{~mm}$, and the distance between them $-86 \mathrm{~mm}$. The test was carried out at a speed of $2 \mathrm{~mm} / \mathrm{min}$, the parameters listed in Table 2 were determined. The number of samples used for testing was according to PN-EN ISO 178.

\section{Charpy's impact with notch}

Impact strength tests were performed to determine the behavior of the materials at a higher deformation rate. The samples used for this test were without a notch and with a normalized V-notch. The cut depth was $2 \mathrm{~mm}$. The impact strength is the work necessary to dynamically break a sample relative to its cross section. Charpy's impact strength was determined according to PN-EN ISO 179-1 using a hammer drill. Attention was paid to the required impact speed and range of the device under the influence of absorbed energy, the value of which should be from $10 \%$ to $80 \%$ of the available energy of the hammer. A $2 \mathrm{~J}$ and $7.5 \mathrm{~J}$ impact hammer were also calibrated and used. The losses of absorbed energy at the start were $0.020 \mathrm{~J}$. The 
$\mathrm{T}$ a b 1 e 3 . Bending strength test results

\begin{tabular}{c|c|c|c|c|c|c|c}
\hline $\begin{array}{c}\text { Symbol } \\
\text { of sample }\end{array}$ & $\begin{array}{c}W \\
\mathrm{~mm}^{2}\end{array}$ & $\begin{array}{c}\delta \mathrm{fC} \\
\mathrm{MPa}\end{array}$ & $\begin{array}{c}\sigma \mathrm{fB} \\
\mathrm{MPa}\end{array}$ & $\begin{array}{c}\sigma \mathrm{fM} \\
\mathrm{MPa}\end{array}$ & $\begin{array}{c}\varepsilon f \mathrm{f} \\
\%\end{array}$ & $\begin{array}{c}E(\mathrm{~b}) \\
\mathrm{MPa}\end{array}$ & $\begin{array}{c}s \mathrm{~B} \\
\mathrm{~mm}\end{array}$ \\
\hline $\mathrm{K} 3$ & $26.7 \pm 0.9$ & $160 \pm 1.8$ & $274 \pm 1.9$ & $8.1 \pm 0.4$ & $4.2 \pm 0.2$ & $8200 \pm 100$ & $12.9 \pm 0.6$ \\
K4 & $26.7 \pm 0.8$ & $225 \pm 2.3$ & $306 \pm 2.4$ & $9.7 \pm 0.6$ & $3.4 \pm 0.2$ & $13000 \pm 150$ & $10.4 \pm 0.4$ \\
K5 & $26.7 \pm 0.9$ & $217 \pm 1.9$ & $304 \pm 2.6$ & $8.2 \pm 0.5$ & $3.5 \pm 0.3$ & $12000 \pm 120$ & $10.7 \pm 0.5$ \\
K6 & $26.7 \pm 0.7$ & $260 \pm 2.2$ & $315 \pm 3.1$ & $8.2 \pm 0.4$ & $2.5 \pm 0.1$ & $13000 \pm 150$ & $7.8 \pm 0.4$ \\
K7 & $26.7 \pm 0.8$ & $190 \pm 2.1$ & $225 \pm 2.2$ & $8.1 \pm 0.3$ & $2.6 \pm 0.1$ & $8900 \pm 100$ & $8.2 \pm 0.5$ \\
\hline
\end{tabular}

$\mathrm{T}$ a b 1 e 4 . Impact and hardness determination results

\begin{tabular}{|c|c|c|c|c|}
\hline Symbol of sample & $\begin{array}{l}\text { Charpy's impact without } \\
\text { notch, } \mathrm{kJ} / \mathrm{m}^{2}\end{array}$ & $\begin{array}{l}\text { Charpy's impact with } \\
\text { notch, } \mathrm{kJ} / \mathrm{m}^{2}\end{array}$ & $\begin{array}{c}\text { Hardness by Shore D } \\
\text { `Sh }\end{array}$ & $\begin{array}{l}\text { Hardness by Rockwell } \\
\mathrm{N} / \mathrm{mm}^{2}\end{array}$ \\
\hline K1 & no fracture & $9.1 \pm 0.4$ & $73 \pm 0.9$ & $111.5 \pm 2.3$ \\
\hline K2 & no fracture & $5.8 \pm 0.3$ & $74 \pm 0.8$ & $143.6 \pm 2.1$ \\
\hline K3 & $3.2 \pm 0.2$ & $13.1 \pm 0.6$ & $78 \pm 1.1$ & $207.8 \pm 2.6$ \\
\hline K4 & $3.6 \pm 0.2$ & $13.4 \pm 0.5$ & $81 \pm 0.9$ & $261.5 \pm 2.9$ \\
\hline K5 & $3.8 \pm 0.3$ & $16.0 \pm 0.7$ & $81 \pm 0.8$ & $262.1 \pm 2.3$ \\
\hline K6 & $2.7 \pm 0.1$ & $11.3 \pm 0.6$ & $83 \pm 1.2$ & $276.3 \pm 2.1$ \\
\hline K7 & $1.9 \pm 0.1$ & $8.0 \pm 0.2$ & $85 \pm 1.1$ & $299.7 \pm 2.9$ \\
\hline
\end{tabular}

cuboidal samples were placed in the base of the instrument and hit by a single stroke pendulum movement at a nominally constant speed. The work needed to dynamically break the mold related to $1 \mathrm{~m}^{2}$ of its cross-section was measured. The number of measurements for each sample was according to polish standard.

\section{Determination of hardness by Shore D}

The hardness measurement was made to determine the resistance of materials to permanent deformations. The test was carried out in accordance with the PN-EN ISO 868 standard. For the tested materials, we used an indenter type $\mathrm{D}$ with a pointed end and a load of $4 \mathrm{~kg}$. The result was read after 15 seconds from the scale in Shore D degrees. The number of measurements for each material was according to polish standard.

\section{Determination of hardness by Rockwell}

The Rockwell hardness determination was made according to PN-EN ISO 2039 using a Zwick/Rockwell hardness tester. A load of $961 \mathrm{~N}$ was used to test the filled materials, i.e. from $\mathrm{K} 3$ to $\mathrm{K} 7$, and $358 \mathrm{~N}$ for unfilled materials. Then, a steel ball was pressed into the surface of the tested samples. The result was read after 30 seconds. The number of measurements for each material was according to polish standard.

\section{RESULTS AND DISCUSSION}

\section{Analysis of bending strength results}

Three-point bending was carried out for materials filled with glass fiber (K3-K7). Five fittings of each type were stretched. The average results are in Table 3.
The results show that the composites had similar bending strengths. The highest value was achieved for the K4 material. What's more, this material has a high modulus of elasticity. Better results were obtained only for the $\mathrm{K} 6$ composite. The difference between them was about $4 \%$. The worst result - almost $60 \%$ lower - was obtained for $\mathrm{K} 3$.

\section{Charpy's impact without notch}

The obtained results are presented in Table 4 . In the case of $\mathrm{K} 1$ and $\mathrm{K} 2$ materials, no fracture of the sample occurred. In the remaining cases, total fracture was observed. The difference between minimum and maximum impact strengths was almost $100 \%$. The lowest value was gained for $\mathrm{K} 7$ (approx. $48 \mathrm{~kJ} / \mathrm{m}^{2}$ ). Comparable and the greatest values were achieved for composites based on polyamide 66 containing 50 wt \% of glass fiber (K5).

\section{Charpy's impact with notch}

Table 4 summarizes the results obtained during the Charpy notched impact test. Based on the results, it can be seen that the smallest work for dynamic fracture of the sample is needed for unfilled PA66 (K2). The highest result was achieved for a PA66 composite with $50 \mathrm{wt} \%$ of fiber - K5. Comparing the results of the notched impact test, the difference in value between composites on the same base and equally reinforced (K4 and K5) is clear - about $20 \%$. It is also worth paying attention to the comparable result for compositions K3 and K4. K4 material contained 15\% more glass fiber, and the difference in impact strength is only about $2 \%$. 


\section{Results for determining Shore D hardness}

Table 4 shows the average Shore D hardness determinations. Based on the results, it can be seen that the smallest value was obtained for samples with PA6 (K1). The best result was obtained for the composite based on PPA6 + 30wt \% of FG - K7.

\section{Results of determining Rockwell hardness}

Based on the results summarized in Table 4 of Rockwell hardness, we observe that the worst results were gained for unfilled PA6 and PA66 (K1 and K2). Composites from K3$\mathrm{K} 7$ gave much greater hardness values and therefore tests were carried out using a greater load. The greatest hardness of Rockwell was for the K7 composite - on a PPA base reinforced with $30 \mathrm{wt} \%$ of glass fiber. Comparing this result to the PA66 composite with a $35 \mathrm{wt} \%$ of fiberglass content (K3), we observe an approx. $45 \%$ increase in Rockwell hardness.

\section{CONCLUSIONS}

From the data, it can be stated that:

- Composites based on PA66 and PPA containing between 30 and $50 \mathrm{wt} \%$ of glass fiber have similar bending strengths.

- An increase in the content of fiberglass in PA66-based composites increases the value of the modulus of elastic- ity by approx. 56\%. An inverse relationship was achieved for PPA composites.

- The increase in fiberglass content in PA66 composites results in the need to use much more work in order to dynamically break the sample. The lowest impact strength was observed for the PPA composite with $35 \mathrm{wt} \%$ of fiberglass.

- The Shore hardness of the tested composites increases with increased fiberglass content. The composite based on PPA containing $30 \mathrm{wt} \%$ of fiberglass has a higher Rockwell hardness by $45 \%$ than the PA66 composite with $35 \mathrm{wt} \%$ of fiberglass.

- The tested composite materials can be successfully used in the production of substitutes for machine elements made of metal.

\section{REFERENCES}

[1] Singh A.K., Singh P.K.: Proceedings of the Institution of Mechanical Engineers, Part J: Journal of Engineering Tribology 2018, 232 (2), 210. https://doi.org/10.1177/1350650117711595

[2] Oleksy M.: „Materiały polimerowe stosowane na elementy maszyn", Oficyna Wydawnicza Politechniki Rzeszowskiej, Rzeszów 2019, ISBN 978-83-7934-284-6.

[3] Budzik G., Magniszewski M., Przeszlowski Ł. et al.: Polimery 2018, 63, 830. http://dx.doi.org/10.14314/polimery.2018.11.13

Received 30 X 2019. 